\title{
Aplikasi Penunjang Memacu Produktivitas Riset
}

..

Berikut ini profil kami di Publons:

https://publons.com/researcher/2216808/ismail-suardi-wekke/.

Saya menggunakan Publons ini untuk keperluan mengumpulkan jejak rekam review paper yang sudah saya selesaikan.

$\cdot$.

Saya perhatikan, Publons mereview secara manual usulan yang kita ajukan untuk ditambahkan ke dalam profil Publons reviewer.

Kedua, fitur yang menunjukkan aktivitas review tidak saja soal jumlah, tetapi dengan keterangan yang lengkap dengan judul artikel di jurnal yang selesai proses review, dan juga ketika artikel terbit setelah review akan ditampilkan ke publik sesuai dengan regulasi editor jurnal.

..

Ada yang ditampilkan lengkap, sehingga tidak lagi status double blind berlanjut karena penulis dan reviewer saling mengetahui nama. Ada juga jurnal yang tetap mempertahankan status double blind.

Proses verfikasi tidak sampai 2 hari, kurang dari 48 jam. Usulan saya ada yang ditolak, karena pihak Publons tidak menerima sertifikat sebagai bukti tetapi merupakan aktivitas yang menunjukkan review.

Bisa dengan email, atau bahkan screeshot dari aplikasi yang digunakan seperti OJS. Bagian akhir OJS, ada email, sehingga dengan email pernyataan selesai review, dapat dikirimkan ke Publons untuk diverifikasi.

..

Apakah jurnalnya harus terindeks Publons? saya tidak memahaminya dengan pasti. Namun, saya turut mereview artikel di jurnal IAIN Parepare, baru masuk tahun kedua, sudah online pula, saya ajukan ke Publons dan diterima.

..

Saya memandang bahwa Publons ini dapat digunakan untuk menunjang bukti fisik akreditasi, baik program studi maupun institusi. Ini terkait dengan pertanyaan rekognisi dosen.

$\cdot$.

Jika memerlukan, silahkan digunakan.

..

Sebelumnya, artikel ini ditayangkan di Facebook, dengan tautan:

https://www.facebook.com/ismailsuardiwekke/photos/a.1887162914853804/2708058056097615/?ty pe $=3 \&$ theater. 